\title{
TABELA AND FISH FARMING ARE LOCAL WISDOMS ETHNIC SUMATERA FOR SUPPORTED ON SUSTAINABLE AGRICULTURE IN NORTH SUMATERA, INDONESIA
}

\author{
Ameilia Zuliyanti Siregar ${ }^{*}$ \\ Agroteknologi Department, Faculty of Agriculture ,USU, Medan 20155 \\ Corresponding author :Ameilia@usu.ac.id, azsyanti@gmail.com
}

\begin{abstract}
Direct seeding (Tabela) and fish farming (Minapadi), traditional methods used for produce paddy plantation and animal proteins for sustainable food security in Northern Sumatra were done. This study was conducted using a combination of methods to the study of literature (data collectively in USU Library and library of USM) and observations in the fields (lowland and terrace from Langkat district and Smalungun district were conducted since December 2016 to March 2017. As much as two types of rice crops (Ciherang and IR 64) are cultivated showed the status (prey and predator) of insects in Langkat and Simalungun districts respectively. Direct Seed (Tabela) in Langkat agoecosystems applied to irrigated rice, rainfed and tidal land is an alternative model of technology and integrated crop management approach is environmentally friendly. Besides, fish farming (Minapadi) was done in Simalungun district consumed by the family farmers and partly as sold as an additional revenue. The problems are identified from Tabela and Minapadi farmers in Langkat and Simalungun, cosist of technology advice is difficults; do not answer problems; innovation technology creates new problems for farmers due to lack of appropriate with the socio-economic-culture; application of technology requires a high cost while remuneration derived less adequate; systems and counseling strategies are still weak so not able to convey the message properly; indifference farmers to offer new technologies; the existence of uncertainty in control of resources. Food security system with integrated farming through seeded fields and fish farming consept on three of the managements, such as: integrated crop management, integrated pest management and integrated nutrient management based on local knowledge should be cultivated and preserved in Indonesia. The importance of communication, improve interpretation and knowledge of paddy farmers, the adoption of technology and infrastructure empowerment in agriculture, especially in North of Sumatera were increase the productivity of rice farmers in Northern Sumatra.
\end{abstract}

Keywords: Tabela, fish farming, local wisdom, sustainable agriculture, North of Sumatera

\section{INTRODUCTION}

The National Development Goals include improving the welfare of Indonesian people through increasing farmers' income. One of optimizing the potential of irrigated land and increase farmers' income is to manipulate the soil using appropriate technology. The way to do that is to change the system of monoculture to diversified farming systems, through direct seeding and cultivation of rice mina. Seeding is done on a muddy rice field that has been processed completely. Wet seeded been commonly used overseas in areas with assured irrigation. However, the application can not be separated from the wet seeded constraints encountered, namely: 
1. Raising seeded only suitable for flat rice fields and have been processed perfectly. The seeds will not grow when it falls on the ground waterlogged.

2. seeding suitable for irrigated rice technically manageable irrigation. Less appropriate seeding is done in the rainy season. When high rainfall, especially during the recent spread of seeds, the seeds can be carried away.

3. Seed newly deployed relatively more vulnerable to pest birds or rodents.

4. Weeds can grow more rapidly than rice seeds were planted, so the effort membutukan penggendalian more intensive weed.

5. Enterprises are also more intensive replanting activities, due to seed damage due to pest attacks or layout so planting more presentable.

So the system is very suitable to be applied to the seeded fields irrigated land well, not easily flooded, and the processing of the soil has to be perfect, where the condition of the soil is loose and flat. If applicable, will benefit other than labor-saving, namely age seeded rice plants about 15 days faster than the rice plant-growing system moving. This is because the system is seeded rice, the rice plants are not stagnated growth. Other benefits include faster growing root system so it can compete with the weeds to get nutrients in the soil. This is because the root system is not buried in the soil, it is easy to absorb air to breathe. In contrast to the rice crop-planting system to move the stagnant growth during the seedling nursery moved from land to land cultivation. When removed, the plants need time to adapt to the new environment. And habits of farmers over the years, dibenam plant seeds in the ground until all the roots down. This condition causes the root system to grow less rapidly.

Seeded rice systems can be done manually or with the help of tools. Seeding manually only purpose is to save labor, but the rice crop production is less than optimal. With the manual method, the layout of the rice seed is irregular, so the less than optimal growth and complicate the pemeliharaanya. If you want a more regular, do replanting require more power. When this has been done seeded fields development tools. With the layout tools seed more regularly. However, tools exist now does not have optimal performance with the desired result of farmers in general, the layout neat good seed in drills and rows, the seeds that fall every clump of the same amount. If there is a tool whose performance as it was no longer needed replanting activities. To produce optimal growth of the rice plant, before it spread seeds should be given special treatment (seed treatment), as an immunization effort against pests and disease and to stimulate root growth. This way faster root growth so as to compete with the weeds to compete for nutrients. Already many chemical products such circulating in farm shops. In addition, should the number of seeds per clump quite two grains with spacing wide enough to $\pm 45 \mathrm{~cm}$. In this way, the need for fewer seeds, but the growth is more optimal. Habits are now generally applied by farmers are planting rice seedlings each clump amount of 4-5 seeds at a spacing of $25 \mathrm{~cm}$. The way these farmers considered will result in higher productivity due to the number of seeds more automatic tiller number will be more, and with shorter spacing automatically the number of clumps too much. However, based on research results, when each clump only 2 seed with wide spacing, the space for looser tillering. Air circulation and light is also better. This method can optimize the productivity of rice plants.

For the maintenance, wet seeded with move-cropping system there is no difference. Condition problem weeds, wet seeded weeds are usually more dominant. The nature of weeds that can grow more easily beating the growth of rice plants in 
wet seeded land. If the system is movedcropping land, which is planted rice seedlings already growing, while the seeds gulm that is in the land has not grown. So the growth of weeds is too late. To deal with them can by hand (Java Language: diwatun) or by chemical means using rice herbicide. With the maintenance of fish in rice fields, in addition to increasing the diversity of agriculture, increasing farmers' income, improve soil fertility and water, can also reduce pest in rice plants. Fish farming cultivation is also the best solution in the face of extreme climate change today. Fish farming cultivation techniques consist of two patterns that can be done in a single growing season, ie penyelang patterns and intercropping. Methods use of fish farming before the rice planting rice seedlings while waiting for the results to be planted as farmers in the village of Manik Rambung, Simalungun district.

While cropping intercropping is the maintenance of fish/shrimp along with rice in a paddy field as many farmers in Serdang Bedagai and Langkat. Fish farming farm system has been developed in Indonesia since a century ago (Ardiwinata, 1987; Afrianto and Evi, 1998). At first Fish farming cultivation system known in China over 1700 years ago. Fish farming began to be applied in Thailand more than 200 years ago (Fedoruk and Leela Patra, 1992). In Indonesia, Fish farming practice began to be known before 1860 in Ciamis, West Java (Koesoemadinata and Costa-Pierce, 1992). Development Fish farming stricken Central Java, West Java, North Sumatra and South Sumatra, North Sulawesi, Bali, and Lombok taken by students (students), merchants, and government officials (Fagi, et. al., 1992). Fish farming development currently allows in line with the development of rice field irrigation system is driven by the role and policies of the government. In 1934, the development of many Fish farming directed to areas outside Java. In the 1950s, Fish farming cultivation has spread in the islands in Indonesia. At this time Fish farming planting area reached 50,000 ha with an average production of $100 \mathrm{~kg} / \mathrm{ha} / \mathrm{yr}$. Extensive rice cultivation increased rapidly in 1960-1969, and declined in 19741979 with the imposition of agricultural intensification program by the government program known as the "Panca Usaha Tani" in BIMAS program by the Department of Agriculture.

However, during 1980-1984, rapidly increasing rice areas reached 137 384 ha in 1982. Almost all the development areas of Fish farming berloaksi in Java. In 1985, the area planted with rice in Java and Sumatra reached 69\% to $15 \%$ of the total rice cultivation in Indonesia. Aquaculture production of Fish farming in 1975-1985 reached approximately $200 \%$ increase in almost all regions in Indonesia. In addition to providing a source of food carbohydrates, the system also provides a protein that is good enough to improve food quality in rural population (Syamsiah et.al., 1988). With the right technology, Fish farming can give a high enough income and an additional protein source for the family farmers.

The benefits of Fish farming farming by increasing the production of rice and fish, reduce the use of pesticides, inorganic fertilizers, weeding and tillage (Suriapermana and Syamsiah, 1995). Mina rice is a fish-breeding activities in the fields where paddy form are such that make decent fish life. In paddy fields, for pisciculture made a kamalir on the side of the pool or pond which was made amid a maintenance function for ikan.Ikan reared in the rice paddies to the size of the seed is very good because the rice fields generated many natural foods that can directly help the growth of the fish. In addition to natural forage fish need feeding also made in the form of cassava bran, vegetables, or 
pellets in order to achieve optimum growth.

How exactly Fish farming aquaculture development in Indonesia to become one of the strategies of aquaculture in improving aquaculture production nationally? According to statistics of aquaculture Indonesia published by the Directorate General of Aquaculture, most areas of Indonesia is already floating the cultivation Fish farming. Most farmed fish is carp and tilapia, although in fact is not limited between the two commodities. Commodities other fish that can be cultured by this method, among others: nilem, tawes, catfish, mujaer, carp and prawns. If looked upon by the data in 2009, the total production of paddy cultivation is the largest mina West Java province amounted to 31784 tonnes, followed by East Java Province amounted to 11879 and South Sumatra amounting to 10660 tonnes. Cultivation Fish farming highly developed in Java and Sumatra, supported by other islands. However the present time cropping patterns Fish farming limited to just some areas in North of Sumatera, including those that are still often found in Simalungun, Bedagai Serdang, Deli Serdang and Langkat.

Fish farming cultivation technique is actually not difficult. Noteworthy in fish farming with rice cultivation techniques mina This is the type of rice varieties and species of fish that have absorption and high economic value. Selection of fish species also need to consider the availability of water, seed, feed and market share of the farmed fish and sold later. Potential development Fish farming cultivation still very wide. Potential data released by the Directorate General of Aquaculture, nationwide utilization of land for the cultivation of rice mina only amounted to 127.944 hectares of potential land area of 1,538,379 hectares. So the level of utilization of land for paddy cultivation only about 8.3 percent.
Therefore, the Ministry of Maritime Affairs and Fisheries through the Directorate General of Aquaculture promote aquaculture in fish farming programme. Rice to support aquaculture production target in 2014.

Interest mMinapadi system paddy in the village of Manik Rambung, North Sumatra are:

1) To Support increased land productivity.

2) To increase farmers' income.

3) To increase the quality of food for the community.

Many advantages when using this technique Fish farming cultivation, among others, namely:

1. Rice fields into fertile with fish feces that contain nutrients.

2. Reduce the use of fertilizers.

3 . Fish restrict the growth of other plants rice in the utilization of nutrients.

4. Reduce the cost of weeding the weeds.

5 . Increasing rice productivity by $10 \%$.

In a scientific study conducted by the Research Institute for Freshwater Aquaculture Bogor shows that the application of Fish farming cultivation could increase revenue by $20 \%$, while using direct seeding systems will increase the agricultural productivity of more than $50 \%$ of hadil planting rice seeds using a maintenance system.

According to Hidayat (2000) in Sunaryo and Joshi (2003), indigenous knowledge is a set of knowledge created by a group of people from generation to generation that lived fused and in harmony with nature. Such knowledge is growing in local scope, adjusting to the circumstances and needs of the community. This knowledge is also the result of the creativity and innovation or trial continuously involving internal input and influence externally in an effort to adjust to the new conditions local. Therefore, this indigenous knowledge can not be 
interpreted as ancient knowledge, backward, static or unchanging.

Indigenous knowledge is growing through the oral tradition of mouth-tomouth or through informal education and the like and always get additional of new experiences, but this knowledge also may be lost or reduced. Of course, knowledgeknowledge not relevant to the changing circumstances and needs will be lost or abandoned. Farmers' capacity to manage change is also a part of indigenous knowledge. Thus, knowledge indigenous can be seen as an accumulation of collective experience generation to the dynamic and ever-changing constantly changing times.

Agricultural used of seeded systems and fish farming are a alternative ways from local wisdoms that should be preserved cultivated in Indonesia. Food security system with integrated farming through Fish farming that berkonsepkan third blend, namely integrated crop management (integrated crop management), integrated pest mnagement (integrated pest management), and integrated nutrient management (nutrient management, integrated) very profitable for farmers to improve their living standards, local wisdom so our nation's culture one of them with a system of rice mina friendly environment is a strategy in the management of sustainable agriculture in Northern Sumatra.

\section{METHODOLOGY}

This study was conducted using a combination of methods to the study of literature (data collectively in USU Library and library of USM) and observations in the fields (lowland and terrace) from Langkat district and Simalungun district were conducted since January 2017 to March 2017. As much as two types of rice crops (Ciherang and IR 64) are cultivated showed the status (prey and predator) of insects and pests in langkat and Simalungun districts respectively. The analysis data was done using SPSS version 14.00

\section{RESULTS AND DISCUSSIONS}

There are several reasons why technology and information offered denied farmers in Langkat and Simalungun districts, among others: (1). Technology advice often do not answer problems faced by farmers target; (2). The technology offered farmers and may be difficult to implement no better than existing local technology; (3). Innovation Technology creates new problems for farmers due to lack of appropriate with the socioeconomic-culture;

Application of technology requires a high cost while remuneration derived less adequate; (5). Systems and counseling strategies are still weak so not able to convey the message properly; (6). There is indifference farmers to offer new technologies, often from of bad experiences in the past; (7). The existence of uncertainty in control of resources (land, etc.).

Policy holders, experts or researchers sometimes less be able to understand the constraints and opportunities that develop in the community so the technology is advisable not to touch on the roots the existing problems. Thus, dissemination of technology not right to many who were not adopted by the community. Experts farming community argue that the failure to adopt the technolog recommendation due to their conservative, irrational, lazy or stupid (Sunaryo and Joshi, 2003), but more due engineering technology such recommendations are not in accordance with the conditions socio-economic and ecological farming community.

Technological developments are basically inseparable from development of 
society in addressing the changes or dynamics the environment in which they live. Long story and the natural occurrence of where they lived became a source of inspiration, including responses them in overcoming the natural fluctuation important notes they, who then told from generation to generation as knowledge in dealing with nature and its amendments.

Direct seeding (seeding) take 7 the following components: land clearing and land preparation; use of improved seed; pengelolalan water, soil and good irrigation; inadequate infrastructure; seeded process systematically; post-harvest management (Jaya et al., 2004). While the local knowledge of farmers in langkat masyarakata communally called berahoi (Bahorok society) in the past describe the life cycle of farming, such as trowel, seedlings, planting, harvesting, and others as well as through art and culture berahoi involving ceremonies and traditions. Historically the Malay community generally by way of planting rice farming, though in some places they go to the field in accordance with the residential area. Malays called grains of rice (Oryza sativa) with the name of rice. This name is a grain that has been peeled and cooked rice is rice that has been cooked. The types of rice are classified into two parts rice paddy fields and rice paddies. Berahoi tradition in the Malay culture characterized bohorok North Sumatra and patterned thinking agrarian society. Both forms of this society, that farmers and fishermen are generally categorized as rural communities (rural). Tradition Berahoi can be categorized as an oral tradition in relation to the process and the results of the process of verbal communication and non-verbal transmitted orally within the meaning of oral tradition is said Vansina (2014) that the expression of the oral tradition refers to two things: a 'process' of delivering a message from mouth to mouth for some time until the message disappears and the 'processing' in the form of verbal messages earlier that at least a generation old.

Finnegan (1992) considers oral tradition as a "development" and "modernization" that the process of analyzing the work orally into the "oral tradition" especially the works of the myths collected from a stranger or folklore-based traditions of Europe, because the focus attention to the originality of research on oral literary works centered on the stage of a 'pure', 'original', or 'traditional' 'not contaminated' by 'external influences'. Stories or songs that are considered 'traditional', 'democracy', or 'tribal / tribal' may be analyzed as the survival of the people some of the previous stages. The assumption forms (tradition) orally from the past who collected the colony / colonies are not European in essence can be analyzed as a form different from the form contained in the oral tradition that comes from (the) Europe, and closer to ' nature 'according to the preconception in the nineteenth century that some still used today (Finnegan, 1992).

Otherwise, in Simalungun society dobe in local wisdomof Minapadi with land clearing and land preparation; use of improved seed; pengelolalan water, soil and good irrigation; inadequate infrastructure; seeded process systematically; post-harvest management with Habonaron do Bona, such as do praise to God, respect for others, must not harm humans, should not be berbohog, cursing, and defraud, and loving plants, animals and other people as well. Rice productivity analysis of treatment there is a real difference using conventional rice farmers $(F=0.048)$, agriculture wet seeded $(\mathrm{F}=0.029)$ and farming system minapadi $(\mathrm{F}=0.038)$ at $\mathrm{P}<0.05$.

Swamp ecosystem has prospects for development fish farming at an early stage is intended to meet the needs of families farmer. In the tidal swamp land, 
the development of fish, especially on land flooded. Fish farming in swampy areas to do with the system pond or rice-fish (fishrice) especially for shallow and swampy lowland mid, both mono and poly. Maintenance can be done with the shelter system, hempang or pen. Types of fish that can live with either in tidal swamp land and jelawat is tilapia (fish farming) and damselfish (wild fish), while that may be developed in the swampy wetlands is Sepat ago, jelawat, catfish, lampan, and Tawes (Ismail et al. 1993). Maintaince system shared fish farming in paddy fields or Fish farming has been developed in Indonesia since a century ago (Ardiwinata, 1987) and is one type of fish farming in the fields, where fish and rice planted together (Agricultural Information Center Irian Jaya, 1992) .

Otherwise, the fields suitable for farming are rice floded technical or semitechnical (Mujiman, 1987). Tupan et al, (2013) says that the cultivation system Fish farming is a way of fish farming on the sidelines of paddy fields; as other plants between the two seasons of rice plants and or maintenance of fish as substitute crops in paddy fields. It can enrich the planting medium with organic fertilizer and increase the production of plankton which is the source eating fish, and that fish contribute to the integrated farming this (Simanjuntak, 2013).

Even according to Montazeri (2012) is one technology Fish farming agricultural land for the improvement of environmental quality in anticipation climate anomalies, because this Fish farming is an integrated aquaculture can increase the productivity of paddy fields, namely: increase farmers' income through increased rice production is $10 \%$; increase the diversity of agricultural products because it produces a fish; increasing soil fertility and water (reducing of fertilizer is $30 \%$ ); also can reduce the brown planthopper pest on plants paddy.
Fish farming farming systems are classified into 3 categorized, such as:

1. Aquaculture and other plants in the rice Pisciculture as penyelang, conducted after the paddy soil is done while awaiting planting maintenance padi.Lamanya usually 20-30 days, until the moment the seeds are ready to be planted. In this system, usually only done for nursery fish seed (size $1-3 \mathrm{~cm}$ ) dengantujuan: after age 20-30 days, the results dederan turns into a fish ready strewn pool (size 3-5 cm or seeds).

\section{Aquaculture-rice plantation}

A pisciculture in paddy field along with paddy. The time of maintenance since rice seed is planted until the first weeding, weeding second, or until the rice plant flowering (begin to form), even drying. Harvests may be fish measuring 100 grams/fish

\section{Aquaculture Instead of Crops of} Leguminose (Palawija)

Maintenance is carried out as a substitute crops in the pattern rotation of rice crops to restore soil fertility padi. In the generally, pisciculture as pulses, carried out after two rice planting seasons in a row, or rice-rice-fish (Anonymous 1985).

\section{CONCLUSIONS}

Direct seeding (Tabela) and fish farming (Minapadi) can be cultivated and developed in an agricultural farms in Indonesia, including in the lowlands and the highlands of ricefield in North of Sumatra. The advantages to be gained from fish farming Fish farming system is obtained by two kinds of production was rice and fish. Tabela and fish farming with wet seeded rice can increase family incomes; farmers have adopted knowledgment and technology; fishes wastes are used for fertilizer in the rice 
crop; improve soil structure for fish in search of food are always flipping back the mud in helping circulation farmland; biocontrol of pests in the rice crop, as well as obtaining additional sources of protein for the people of the fish that have economic value. Hopefully the cultivation of direct seeding and fish farming into adoption in local knowledge of farmers Batak ethnic, Javanese, Dayak, Banjar, Madura and other ethnics in the Northern Sumatra and preserved in improving the welfare of Indonesian people through increasing farmers' income. Food security system with integrated farming through seeded fields and fish farming berkonsepkan blend of three of the management: integrated crop management, integrated pest management and integrated nutrient management based on local knowledge should be cultivated and preserved in Indonesia. The importance of communication, improve interpretaion and knowledge of paddy farmers, the adoption of technology and infrastructure empowerment in agriculture, especially in North of Sumatera.

\section{ACKNOWLEDGMENT}

I would say thank you to the Directorate General of the Ministry of Education National top gives the cost of research in the National Strategic Grant program 2010/2011. To Mr. Tanjung, Mr Andri in Langkat district, Mr. Silalahi, $\mathrm{Mr}$ Nainggolan, and $\mathrm{Mr}$ Hutapea in Simalungun district and people of other farmers in Langkat and Simalungun that help lend the land in the study and share experience in developing direct seeding (Tabela) and Fish farming (Minapadi), thanks for the help and good favor is remembered for all times.

\section{REFFERENCES}

Afrianto, Eddy dan Evi Liviawaty. 1998 Several Fish Cultivation Method.
Kanisius,

Yogyakarta. 86-94.

Agricultural Information Center Irian Jaya, 1992. LIPTAN No. 11/1992, 1992. Marine Fisheries Agency daan Bengkulu province, 2012. Harvest Reports Prime Fish farming Event Director General of Aquaculture In the village Penanjung Long District Subdistrict Tebat Karai Kepahiang, Irian Jaya.

Anonymous, 1985. Instructions Fish Cultivation in Rice, Production Enhancement Project Fisheries West of Java. UPP Freshwater of Aquaculture, West of Java.

Anonymous. 2006. Marketing aspect nursery cultivation and rearing of fish of gourami. http://www.bi.go.id/sipuk/Im/ ind/carp/marketing. htm. Access on 18 December 2016.

Anwar, K., M. Alwi, S. Saragih, A. Supriyo, D. Nazemi, and K. Sari. 2001. Characterization of Soil and Water Dynamics for Management Improvement Tidal Land. Final Report of Research. Research Institute Food Crop Land Swamp. Banjarbaru. pp. 27 -28.

Ardiwinata, R.D. 1987. Rice-fish culture on paddy fields in Indonesia. Proceedings of Indo Facific Fish Council (II-III): 11-154.

Fagi, A.M., S. Suriapermana, dan I. Syamsiah. 1992. Rice-fish farming research in lowland area: the West Java case. In C.R. Dela Cruz, C. Lihtfoot, B.A. Costa Pierce, V.R. Carangal, and M.P. Bimbo (Eds.). Proceeding of Rice-Fish Research and Development in Asia. ICLARM Conf. Proc. pp. 273-286.

Fedoruk, A and W. Leela Patra,. 1992. Ricefield fisheries in Thailand. In C.R. Dela Cruz, C. Lightfoot, B.A. Costa Pierce, V.R. Carangal, and M.P. Bimbo (Eds.). Proceeding of 
Rice-Fish Research and Development in Asia. ICLARM Conf. Proc 12. 261p.

Hickling, C.P. 1971. Fish Culture. Faber and Faber. London. p. 253.Fedoruk dan Leelapatra, 1992. Koesoemadinata and Costa-Pierce, 1992. Status of rice-fish culture in Indonesia. in: C.R. de la Cruz, C. Lightfoot, B.A.Costa-Pierce, V.R. Carangall and M.P. Bimbao (Eds.). Rice fish research and developmet in Asia ICLARM,Manila, Phillipines. pp.45-62.

Hidayat, T. 2000. Studies of cultural wisdom in the management of farmers Banjar tidal swamp land. Faculty of Agriculture, University of Lambung Mangkurat, Banjar Baru. Journal of Borneo Agrikultura 7 (3): 105-111.

Hepher, B., and Y. Pruginin. 1981. Commercial fish farming with special reference to fish culture in Israel. John Wiley and Sons, New York. 261p.

Hickling, C.F. 1971. Fish culture. Faber and Faber, London. 348 p.

Ismail, I.G ., Alihamsyah, Widjaja Adhi, I.P.G ., Suwarno, Herawaty, T ., Tahir, R and Sian, D.E. 1993. Eight Years of Agricultural Research in Land Swamp: Contribution and Development Prospects. Swamps Project II. Research and Development Crops. Bogor. Office of the Deputy Menegristek Administrative Reform and Correctional Science Knowledge and Technology, Bogor .

Jaya, A., Inoue, T., Rielley, J.O, dan Limin, S. 2004. Enviromental change caused by development of peatland landscapes in Central Kalimantan, Indonesia. Dalam Proc. of the 12th Int. Peat Congress: Wise Use of Peatland. Finland. pp. 660-667.
Liptan No. 06/KAN/INF/BIP-SB/89-90. Syamsiah, I., S. Suriapermana, and A.M. Fagi. 1988. Research on Rice Fish Culture: Past experiences and future research programs. Paper Presented at The Workshop on RiceFish Farming Research and Development. Ubon, Thailand, 21-25 March 1988. Suriapermana, S. dan I. Syamsiah. 1995. Legowo row planting on the farm system-Azolla Fish farming in irrigated land. Pp 7483. In Z. Zaini and Sham M. (Ed.). Minutes of the Research Seminar Systems Farming and socioeconomics. Bogor 4 to 5 October 1994. Research and Development Center for Food Crops, Bogor.

Manwan, I., Ismail, I.G., Alihamsyah, T., and Partohardjono. 1992. Technology Land Agricultural Development Tidal Swamp. In: Proceedings National Meeting of Agricultural Technology Development Land Swamp Tidal and Lebak, Cisarua. pp. 7-9.

Sunaryo and L. Joshi. 2003. The role of local ecological knowledge in agroforestry. World Agroforestry Centre (ICRAF) Southeast Asia Regional Office. Bogor, Indonesia.

Suriapermana. S., I. Syamsiah, P. Ward, and A.M. Fagi. 1989.Petunjuk practical rice system-fish and duckling rice in paddy fields. Balittan Sukamandi.

Widjaja Adhi I.P.G; K. Nugraha; D.S. Ardi and U.S. Karama, 1992. Resource Tidal land, swamps, and Coast: Potential, Limitations, danPemanfaatan. Proceedings of the National Land Development Meeting Agriculture Tidal and Rawa. Cisarua, 3 - March 4, 1992. 